\title{
THE PRESENCE OF PERIPHERAL INFLAMMATORY MARKERS IN PATIENTS WITH MAJOR DEPRESSIVE DISORDER, THE ASSOCIATED SYMPTOMS PROFILES AND THE ANTIDEPRESSANT EFFICACY OF CELECOXIB
}

\author{
VIRGIL RADU ENĂTESCU ${ }^{1,2}$, RALUKA KALINOVIĆ ${ }^{2}$, GABRIELA VLAD ${ }^{2}$, LAURA \\ ALEXANDRA NUSSBAUM ${ }^{1}$, LAVINIA HOGEA ${ }^{1}$, ILEANA ENĂTESCU ${ }^{1 *}$, ILEANA \\ MARINESCU $^{3}$, PETRU IFTENI ${ }^{4}$, MIHAELA SIMU ${ }^{1}$, CĂTĂLIN MARIAN ${ }^{1}$, CĂTĂLINA \\ GIURGI-ONCU ${ }^{1,2}$, ION PAPAVĂ $\breve{~}^{1,2}$
}

\author{
1 "Victor Babeș" University of Medicine and Pharmacy, Timișoara, Romania \\ 2 ,Pius Brînzeu" Emergency County Hospital, Psychiatric Clinic, Timișoara, Romania \\ ${ }^{3}$ University of Medicine and Pharmacy, Craiova, Romania \\ ${ }^{4}$ Transilvania University, Brașov, Romania
}

*corresponding author: lena_urda@yahoo.com

\begin{abstract}
Despite the treatability and advances in treatment of major depressive disorder (MDD), treatment responsiveness is still only around $30-50 \%$. The involvement of pro-inflammatory factors in the pathogenesis of major depression is one of the new perspectives of current research. This is a prospective study over an 8-week period in 50 MDD patients with single or multiple episodes recruited from the Timişoara Psychiatry Clinic during 2016-2019. Several psychometric measures were applied and baseline for C Reactive Protein (CRP) and Interleukin-6 (IL-6) blood levels were determined. Among the 17item Hamilton Depression Rating Scale (HAM-D), somatic anxiety, somatic symptoms-general and insight had significantly higher scores in MDD patients with elevated inflammatory markers compared to their counterpart with normal inflammatory marker levels $(\mathrm{p}<0.05)$. Add-on celecoxib treatment determined a significantly lowered mean HAM-D scores at endpoint in MDD patients with elevated inflammatory markers $(\mathrm{p}<0.01)$. Linear regression analysis revealed the presence of inflammation (IL-6 and/or CRP) and add-on celecoxib treatment as significantly influencing endpoint HAM-D scores ( $p<$ 0.01). Routine determination of inflammatory markers in MDD patients, together with add-on celecoxib treatment, generates new opportunities for the clinical management of this highly frequent psychiatric condition in the general population.
\end{abstract}

\section{Rezumat}

În ciuda tratabilității și a progreselor făcute în domeniul tratamentului tulburărilor depresive majore, respondența terapeutică rămâne una modestă variind între 30 și 50\%. Implicarea factorilor pro-inflamatori în patogeneza tulburării depresive majore este una din perspectivele noi ale cercetărilor actuale. Studiul de față este unul prospectiv longitudinal pe o perioadă de 8 săptămâni asupra a 50 de pacienți cu tulburare depresivă majoră, episod unic sau multiplu, recrutați în cadrul Clinicii de Psihiatrie Timișoara în perioada 2016-2019. Au fost aplicate mai multe teste psihometrice și au fost determinate iniţial nivelurile sanguine ale Proteinei C Reactive (PCR) și ale Interleukinei 6 (IL-6). Dintre itemii scalei HAM-D versiunea cu 17 itemi, anxietatea somatică, simptome somatice generale şi conştiinţa bolii au avut medii ale scorurilor semnificativ mai mari în comparație cu pacienții cu tulburare depresivă majoră fără proces inflamator semnificativ $(\mathrm{p}<0,05)$. Tratamentul suplimentar cu celecoxib a determinat o reducere semnificativ mai mare a scorurilor HAM-D la sfârșitul perioadei de studiu în situaţia pacienților cu tulburare depresivă majoră și proces inflamator prezent $(\mathrm{p}<0,01)$. Regresia liniară a identificat prezența inflamației (PCR și/sau IL-6) și a tratamentului suplimentar cu celecoxib, inițiat de la începutul studiului, ambele având o influență semnificativă asupra scorurilor scalei HAM-D de la sfârşitul perioadei de studiu $(\mathrm{p}<0,01)$. Detecția de rutină a markerilor inflamatori și instituirea tratamentului cu celecoxib, când este necesar, la pacienții cu tulburare depresivă majoră deschide noi oportunități în abordarea și managementul clinic al aceste afecțiuni psihiatrice larg răspândite în populația generală.

Keywords: inflammation, major depression, celecoxib

\section{Introduction}

Despite the treatability of major depressive disorder (MDD) compared to other major psychiatric disorders, it was noticed that only about one-third of patients achieve remission in the first treatment step of anti- depressant therapy [1]. Beyond the classical monoamine depletion theory, this evidence comes in support of the argument that additional pathogenetic mechanisms might play a role in depression occurrence, at least in a proportion of patients [2]. 
Over the last decades, a lot of research has evidenced that it could be a link between depression and inflammation, and thus brain-immune interactions might be involved in the pathogenesis of MDD by decreasing the levels of serotonin and noradrenaline $[3,4]$. C-reactive protein (CRP) is a non-specific acutephase protein whose levels are elevated in response to systemic inflammation. Several studies have repeatedly detected that higher levels of pro-inflammatory markers such as CRP and interleukin 6 (IL-6) were associated with an increased likelihood of the development of depression [5-7]. Moreover, one study has shown that among women higher level of CRP was associated with increased severity of depressive symptoms on Montgomery Aasberg Depression Rating Scale (MADRS). Interestingly, no significant associations were found among men, one explanation of the authors being that of differential modulation of immune responses by sex hormones in women compared to men [8]. Besides the association with the severity of depressive symptoms, according to a meta-analysis, the presence of a higher level of CRP has predicted the lack of responsiveness to the antidepressant treatment [9]. Other studies have also suggested that CRP may be considered as a distinctive predictor for antidepressant treatment response and that anti-inflammatory medication could exert an antidepressant effect in depressive patients with an increased level of CRP $[10,11]$.

There are several ways through which macrophage originating pro-inflammatory cytokines can reach the brain, namely leaky regions in the blood-brain barrier (BBB), active transport through transport molecules, cytokine producing cells by activation of several cell types including endothelial cells and perivascular macrophages from the cerebral vasculature, delivering cytokine signals to certain brain regions such as the nucleus of the solitary tract and hypothalamus by binding to cytokine receptors in peripheral afferent nerve fibres such as the vagus nerve $[12,13]$.

At the brain level, a central role in the production of pro-inflammatory cytokines is played by microglia that represents the brain's immune cells. In the context of various situations, such as inflammation, chronic stress, or infection, microglia are activated and release pro-inflammatory signalling cytokines, which in turn, can act on two pathways that ultimately may lead to MDD and neurodegeneration. First, activation of the hypothalamic-pituitary adrenal axis yields an imbalance in the serotonergic and noradrenergic brain circuits [14]. Furthermore, pro-inflammatory cytokines induce gene expression and synthesis of corticotrophin releasing factor (CRF), which stimulates adrenocorticotropic hormone (ACTH) release and causes glucocorticoid secretion [15]. Second, during inflammation, proinflammatory cytokines such as IL-1 $\beta$, IL-2, IL-6, INF- $\gamma$ and TNF- $\alpha$ increase the activity of the enzyme indoleamine-2,3-deoxygenase (IDO), mainly resulting in depletion of serotonin by degradation of tryptophan (the primary amino acid precursor of serotonin) into kynurenine. Kynurenine is further broken down in the CNS into the neuroactive metabolites kynurenic acid and quinolinic acid [15]. Furthermore, quinolinic acid is an endogenous N-methyl-D-aspartate (NMDA) receptor agonist. Activated microglia and infiltrating macrophages are the major source of quinolinic acid in the brain that is implied in the detrimental pathophysiological cascade within the central nervous system (CNS) [16]. Hence, an abnormal and excessive NMDA receptor stimulation accompanied by pro-inflammatory cytokines may inhibit brain-derived neurotrophic factor translation, neurogenesis, determining changes in brain volume, along with dendritic atrophy and synaptic loss. This evidence was also supported by a neuroimaging study that has shown, in healthy male subjects, higher CRP levels were associated with cortical thinning in several left hemisphere perisylvian regions. Also, peripheral IL-6 levels were negatively associated with grey-matter volume in the hippocampus [17-19].

Therefore, we consider that, in some extent, MDD is thought to be associated with increased levels of pro-inflammatory cytokines both in peripheral blood and the brain, which in turn can trigger an inflammatory cascade including cyclooxygenases (COXs) that are key enzymes in the production of prostaglandins. COX-1 and COX-2 are both expressed in the brain, COX-2 being detected in synaptic dendrites and excitatory terminals, predominantly in cortex, hippocampus, and amygdala, while COX-1 is expressed especially by microglia and perivascular cells [20]. COX-1 has been noticed to maintain the inflammatory process and to promote pro-inflammatory up-regulation of prostaglandins in animal models of neuroinflammation [21]. In opposite to COX-1, COX-2 can have either a neurotoxic or an anti-inflammatory role depending on inflammatory context [14]. However, one study has found that the mRNA expression of genes encoding for COX-2 was significantly increased in the peripheral blood cells of recurrent depressive disorder patients compared to controls [22, 23]. Higher level of inflammation results in increasing risk for the occurrence of de novo depression [24].

Considering the evidence for the neuro-inflammation hypothesis in MDD, non-steroidal anti-inflammatory drugs (NSAIDs) have been proposed to be of clinical use in the treatment of depression either as monotherapy or as adjuncts in combination with antidepressants. So far, celecoxib has proved to have neuroprotective and antidepressant effects both in animal and human studies [25]. Celecoxib selectively inhibit COX-2 and induces the impairment of the cascade of enzymatic reactions that transform arachidonic acid to PGEs, prostacyclins, and thromboxanes [26]. However, NSAIDs should be administered only in MDD patients with elevated levels of pro-inflammatory markers considering that one study has revealed that NSAIDs attenuated antidepressant effects of SSRI's 
in both animal models for depression as well as in STAR*D trial participants [27].

Our study aimed to detect the frequency of the increased level of both CRP and IL-6 in a group of patients diagnosed with MDD, along with identifying the clinical patterns of MDD in patients with the increased peripheral pro-inflammatory markers. Finally, we have quantified the additional antidepressant effect of add-on celecoxib treatment in patients with MDD and increased proinflammatory markers.

\section{Materials and Methods}

\section{Participants and study design}

Fifty-two initial patients with MDD who addressed or were referred to the "Eduard Pamfil" Psychiatry Clinic Timișoara, Romania, for psychiatric assistance, were invited to take part in the present study. Of these, two patients subsequently declined to attend all assessment during distinct moments of study.

\section{Inclusion and exclusion criteria}

The inclusion criteria were to fulfil Diagnostic and Statistical Manual of Mental Disorders IV TR (American Psychiatric Association, 2000) criteria for Major Depressive Disorder, single or multiple episode, based on Romanian version of Structured Clinical Interview for Diagnostic and Statistical Manual-IVTR SCID-I [28], aged 18 or above, providing a written informed consent.

The exclusion criteria were the presence of DSM IV TR Axis I major psychiatric disorder other than Major Depressive Disorder, the presence of pregnancy, the participant is unable to provide informed consent, the presence of acute inflammatory disease.
The current study is a longitudinal prospective casecontrol that was carried out over eight weeks, consisted of 5 distinct moments of assessment: at baseline, 2, 4, 6 and 8 weeks. The sampling method was by convenience. The recruitment period was between April 2016 and September 2019.

At baseline, all patients were assessed for depressive symptoms by administering the 17-item Hamilton Depression Rating Scale (HAM-D) by trained psychiatrists. Also, CRP and IL-6 were measured in blood serum. Depressive symptoms were reassessed at 2, 4, 6 and 8 weeks from the baseline.

All patients were treated with escitalopram in doses ranging from 5 to $20 \mathrm{mg}$ once per day in the morning. Depending on associated symptoms (e.g., anxiety or insomnia), alprazolam in doses ranging between 1 - $2 \mathrm{mg}$ twice per day and zolpidem $10 \mathrm{mg}$ at bedtime were allowed.

Depending on the presence or absence of significant levels of peripheral inflammatory markers (CRP and/ or IL-6) and the celecoxib add-on treatment, the study was divided into three arms (the detailed design of study is presented in Figure 1): first arm consisted of patients with MDD but without peripheral inflammatory markers (CRP and/or IL-6) who were prescribed only psychiatric treatment; second arm has comprised of patients with MDD and significant peripheral inflammatory markers (CRP and/or IL-6) who benefited only from psychiatric treatment without celecoxib add-on treatment; third arm encompassed patients with MDD and significant peripheral inflammatory markers (CRP and/or IL-6), but who were prescribed celecoxib $200 \mathrm{mg}$ twice per day.

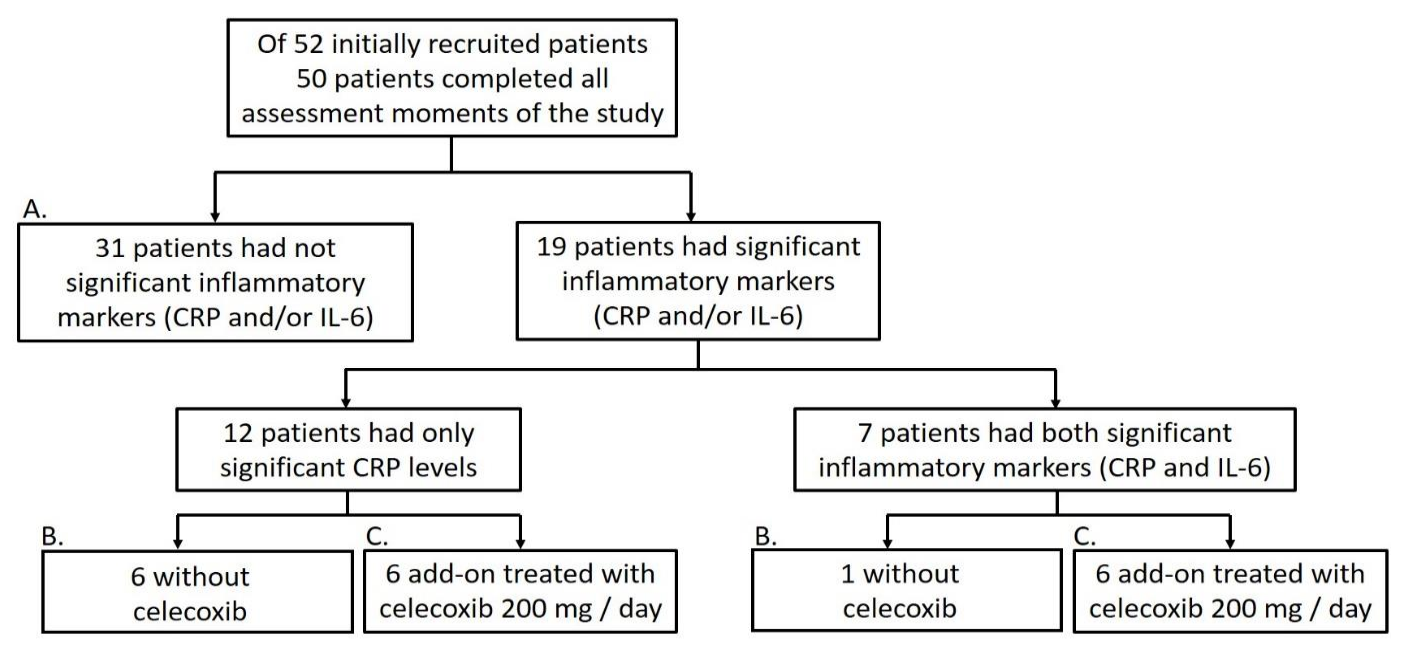

Figure 1.

Schematic representation of the study design

(Note: A - arm A, consisting of MDD patients without elevated inflammatory markers; B - arm B, consisting of MDD patients with elevated inflammatory markers (CRP and/or IL-6) and without add-on celecoxib treatment; C - arm C, consisting of MDD patients with elevated inflammatory markers (CRP and/or IL-6) and add-on celecoxib treatment)

The patients with significant inflammatory markers (CRP and/or IL-6) were assigned to one of these last 2 arms by convenience.
All sociodemographic, case history and clinical data were collected in the same standardized and unitary manner. The self-reported based stressful life events 
occurring during the three months prior to the onset of the current episode and the self-reported based family history of psychopathological conditions among first-degree relatives of analysed patients were also recorded. The presence of the family history of psychopathological conditions was further divided into the nonspecific (psychopathologies other than mood disorders) and specific (psychopathologies belonging to mood disorders).

The study was approved by the Ethics Committee of the Timişoara County Emergency Hospital where the patients were recruited, all subjects providing written informed consent, also respecting the Helsinki Declaration of 1975 regarding research on human subjects.

\section{Measures}

Measurement of the severity of depressive symptoms and clinical profiling of major depressive episode

The severity of depressive symptoms was measured by using the 17-item Hamilton Depression Rating Scale (HAM-D). The HAM-D, a clinician-administered depression assessment scale, consists of 17 items pertaining to symptoms of depression experienced over the past week. A score ranging from 0 to 7 is generally accepted to be within the normal or in clinical remission, while a score of 20 or higher is considered indicating at least moderate severity. In our study, the resulted scores were only treated from a quantitative perspective without using a cut-off score [29].

Measurement of $C$-reactive protein (CRP) and interleukin 6 (IL-6)

Fasting blood was drawn by venipuncture in clot activator vacutainer tubes for serum separation. Blood processing and CRP and IL-6 determination in serum was performed in a certified clinical laboratory (Bioclinica Laboratories, Timișoara). CRP was determined by a latex-enhanced immunoturbidimetric method using the Atellica CH Wide Range C-Reactive Protein assay (Siemens Healthineers, Germany) according to the manufacturer's recommendations in an Atellica CH Analyzer (Siemens Healthineers, Germany). Serum IL-6 levels were determined using a sandwich ELISA method with the Cobas Elecsys IL-6 assay (Roche Diagnostics, Switzerland) according to the manufacturer's instructions.

Data analysis

All statistical analyses were done within STATA version 15 and a p-value $<0.05$ was statistically significant. The Chi-square test was used in order to compare the frequencies of analysed data. Nonparametric tests, such as the Mann-Whitney U and Kruskal-Wallis tests, were used to compare the mean ranks of ordinal data. ANOVA one-way test was performed to compare the means of two or more subgroups of analysed patients. Spearman's rank correlation coefficient was calculated to evaluate the intensity and direction of relationship between ordinal variables. The comparisons have considered either two strata (with and without significant levels of inflammatory markers) or three strata (the significant presence of inflammatory markers was further divided into two subcategories - only significant CRP levels and both CRP and IL-6 significant levels). A multiple linear regression model was carried out to estimate the effect of the presence of inflammatory markers and the initiation of celecoxib treatment on HAM-D depression scores at the endpoint of the study (at 8 weeks). Among the independent variables, the blood levels of CRP and IL-6 at baseline were separately introduced in the linear model as quantitative data. The presence of inflammation (CRP and/or IL-6) was treated as a nominal dichotomic variable. Also, the presence of add-on treatment with celecoxib was introduced as dichotomic nominal variables depending on its presence or absence.

\section{Results and Discussion}

Sociodemographic and case history data depending on the presence or absence of peripheral inflammatory markers

There was no significant difference between the average age of the subgroups with and without significant peripheral inflammatory markers (49.84 vs. 48.47, respectively; $p=0.696$ ) (Table I). Hence, the two strata are comparable, considering that aging could have been a source of confounding factor for our research [30].

Regarding the gender distribution among the patients of the two analysed strata, there also was no significant difference $\left(\chi^{2}=0.016 ; \mathrm{p}=0.899\right)$ (Table I). An unequal gender distribution between the two strata could have influenced the results, given the possible role of sex hormones in modulating immune responses [8]. There were no significant differences concerning the other sociodemographic data, such as educational level, residency, professional and marital distribution among patients in the two compared subgroups $(\mathrm{p}=0.880$, $\mathrm{p}=0.740, \mathrm{p}=0.186$ and $\mathrm{p}=0.344$, respectively), so that they can be considered comparable from this point of view (Table I).

The presence of stressful life events in the last 3 months prior to the onset of the current episode was not significant differently distributed in the compared subgroups $\left(\chi^{2}=0.005 ; \mathrm{p}=0.944\right)$. However, it is worth mentioning that reported-based stressful life events were quite representative being present in almost half of patients belonging to the analysed strata (Table I). According to other research data, psychosocial stressors may alter the immune responses by overactivation and sensitization of the HPA axis [31]. 
Sociodemographic and case history data

\begin{tabular}{|c|c|c|c|}
\hline $\begin{array}{c}\text { Sociodemographic and case } \\
\text { history data }\end{array}$ & $\begin{array}{c}\text { Inflammation markers absent } \\
(\text { CRP and/or IL6), } \mathrm{n}=31(62 \%)\end{array}$ & $\begin{array}{c}\text { Inflammation markers present } \\
(\text { CRP and/or IL6), } \mathrm{n}=19(38 \%)\end{array}$ & Statistical significance \\
\hline Average current age (SD) & $49.84(11.798)$ & $48.47(12.308)$ & $\mathrm{t}=0.393 ; \mathrm{p}=0.696$ \\
\hline Gender - male, $\mathrm{n}(\%)$ & $7(22.6 \%)$ & $4(21.1 \%)$ & $\chi^{2}=0.016 ; \mathrm{p}=0.899$ \\
\hline Educational level, mean ranks & 25.73 & 25.13 & $\begin{array}{c}\text { Mann Whitney U }= \\
287.500 ; \mathrm{p}=0.880\end{array}$ \\
\hline Residency - Urban area, n (\%) & $21(67.7 \%)$ & $12(63.2 \%)$ & $\chi^{2}=0.110 ; \mathrm{p}=0.740$ \\
\hline $\begin{array}{c}\text { Professional status - Employed or } \\
\text { Student, } \mathrm{n}(\%)\end{array}$ & $12(38.7 \%)$ & $11(57.9 \%)$ & $\chi^{2}=1.746 ; \mathrm{p}=0.186$ \\
\hline $\begin{array}{c}\text { Marital status - with intimate } \\
\text { partner, } \mathrm{n}(\%)\end{array}$ & $22(71.0 \%)$ & $11(57.9 \%)$ & $\chi^{2}=0.897 ; \mathrm{p}=0.344$ \\
\hline Stressful life events a $\mathrm{n}(\%)$ & $15(48.4 \%)$ & $9(47.4 \%)$ & $\chi^{2}=0.005 ; \mathrm{p}=0.944$ \\
\hline $\begin{array}{c}\text { Family history of psychopathology a } \\
\text { No history }\end{array}$ & $11(35.5 \%)$ & $8(42.1 \%)$ & $\chi^{2}=0.225 ; \mathrm{p}=0.894$ \\
$\begin{array}{c}\text { Nonspecific } \\
\text { Specific }\end{array}$ & $7(22.6 \%)$ & $4(21.1 \%)$ & \\
\hline
\end{tabular}

The level of significance for all analyses was set at $\alpha=0.05$. The listed percentages are reported to either strata or considered separately. a - Based on self-reporting, CRP = C-reactive protein; IL6 = Inteleukin-6

The family history of psychopathological conditions was nearly equally reported in the two studied strata $\left(\chi^{2}=0.225 ; p=0.894\right)$ (Table I). It has to be noticed that the family history of psychopathological conditions, including both specific and nonspecific, in first-degree relatives was positive for more than half of patients. This result should be carefully interpreted because we consider that it may reflect a direct consequence of the data collection method rather than to any other scientific rationale. However, mood disorders that include MDD should be considered among the most heritable psychiatric conditions [32].

The presence of significant peripheral inflammatory markers and inflammation profiles in studied patients Among the patients who completed all phases of our study $(\mathrm{n}=50), 19$ patients $(38 \%)$ have had significant peripheral levels for at least one of the two assessed inflammatory markers (CRP and/or IL-6). Of these, 12 patients (24\%) have only had significant levels of CRP and 7 patients (14\%) have had significant blood levels of both CRP and IL-6 (Figure 1). None of the patients had only elevated levels of IL-6. These results are in line with data research coming from other similar population-based or clinical studies $[14,24]$. The significantly elevated levels of peripheral inflammatory markers accompanying major depression are more than representative in our research. However, considering the design of the present study, it is difficult to assume the causal relationship between these two conditions. Undoubtedly, large epidemiological studies are necessary to identify the evolution patterns of these co-existing pathologies. The depressive symptoms patterns in patients with elevated inflammatory markers compared with nonelevated inflammatory MDD patients

Concerning the comparisons of HAM-D mean ranks of patients with and without the presence of peripheral inflammatory markers have evidenced several interesting results. Each subgroup of patients with MDD and elevated inflammatory markers (CRP and IL-6 and only CRP respectively) was separately compared with the group of MDD patients and non-elevated inflammatory markers. Thus, patients with MDD and the presence of both elevated inflammatory markers have had significantly higher levels at the items as follows: anxiety - somatic, somatic symptoms -general and insight $(\mathrm{p}=0.001, \mathrm{p}=0.011$ and $\mathrm{p}=0.026)$ compared to non-elevated inflammatory MDD group. Likewise, the subgroup of patients who had only CRP elevated levels presented significantly higher mean scores at anxiety - somatic and somatic symptoms general items $(\mathrm{p}=0.032$ and $\mathrm{p}=0.047)$ (Table II). On the one hand, there could be an overlap between the subjective psychological symptoms expressed by depression and the physical symptoms of somatic conditions in which inflammation could play a critical role. In this case, we are discussing about a state of comorbidity between two distinct diseases that must be investigated carefully, and both conditions should properly be treated to obtain remission. In this regard, many research data have already noticed that MDD is a highly comorbid major psychiatric disorder [33, 34]. On the other hand, MDD with highly significant somatic complaints could represent a specific subtype of depressive experiences in patients with elevated levels of inflammatory responses. In the latter situation, the symptoms expressed at the somatic level have a functional character and the antidepressant treatment will also cause the improvement of these symptoms. Lastly, somatic-like symptoms represent only a distinct facet of the clinical expression of MDD that, to some extent, may be considered a result of a chronic inflammatory state. Therefore, add-on treatment with an NSAID could ameliorate clinical symptoms in combination with antidepressants. 
Table II

Patterns of depressive symptoms depending on elevated peripheral inflammatory profiles (in comparison with subjects with normal blood levels)

\begin{tabular}{|c|c|c|c|c|c|}
\hline \multirow[b]{2}{*}{ HAM-D items } & \multirow{2}{*}{$\begin{array}{l}\text { Non-significant } \\
\text { inflammatory markers a } \\
(\mathrm{n}=31)\end{array}$} & \multicolumn{4}{|c|}{ Elevated inflammatory markers } \\
\hline & & $\begin{array}{l}\text { CRP and IL-6 }{ }^{\mathrm{a}} \\
(\mathrm{n}=7)\end{array}$ & $\mathrm{p}$ value $^{\mathrm{b}}$ & $\begin{array}{c}\text { Only CRP }^{\mathrm{a}} \\
(\mathrm{n}=12)\end{array}$ & $p$ value $^{b}$ \\
\hline 1. Depressed Mood & $2.87(0.763)$ & $3.00(0.577)$ & 0.625 & $2.75(0.622)$ & 0.681 \\
\hline 2. Feelings of guilt & $1.35(0.755)$ & $1.29(0.756)$ & 0.854 & $1.50(0.674)$ & 0.505 \\
\hline 3. Suicide & $0.77(1.055)$ & $1.43(1.813)$ & 0.435 & $1.00(0.853)$ & 0.293 \\
\hline 4. Insomnia - early & $1.71(0.529)$ & $1.57(0.787)$ & 0.769 & $1.50(0.674)$ & 0.296 \\
\hline 5. Insomnia - middle & $1.03(0.836)$ & $0.86(0.900)$ & 0.618 & $0.83(0.718)$ & 0.472 \\
\hline 6. Insomnia - late & $1.42(0.672)$ & $1.57(0.787)$ & 0.472 & $1.50(0.674)$ & 0.704 \\
\hline 7. Work \& Activities & $2.26(0.855)$ & $2.71(0.488)$ & 0.141 & $2.08(0.669)$ & 0.551 \\
\hline 8. Retardation & $1.03(1.140)$ & $1.57(1.512)$ & 0.334 & $1.42(1.165)$ & 0.286 \\
\hline 9. Agitation & $1.45(0.850)$ & $1.71(0.951)$ & 0.400 & $1.58(0.900)$ & 0.708 \\
\hline 10.Anxiety - psychic & $2.26(0.930)$ & $2.71(0.488)$ & 0.204 & $2.33(0.778)$ & 0.861 \\
\hline 11.Anxiety - somatic & $1.74(0.729)$ & $2.86(0.378)$ & $* 0.001$ & $2.33(0.778)$ & $* 0.032$ \\
\hline 12.Somatic symptoms - GI & $1.29(0.824)$ & $1.86(0.900)$ & 0.087 & $1.58(0.515)$ & 0.368 \\
\hline 13.Somatic symptoms - General & $1.23(0.669)$ & $2.00(0.577)$ & $* 0.011$ & $1.67(0.492)$ & $* 0.047$ \\
\hline 14.Genital symptoms & $1.23(0.669)$ & $1.57(0.535)$ & 0.218 & $1.17(0.718)$ & 0.811 \\
\hline 15.Hypochondrias & $1.48(0.769)$ & $1.71(0.756)$ & 0.553 & $1.50(0.674)$ & 0.870 \\
\hline 16. Weight loss & $0.74(0.729)$ & $0.71(0.488)$ & 0.934 & $0.75(0.866)$ & 0.930 \\
\hline 17. Insight & $0.29(0.588)$ & $0.71(0.488)$ & $* 0.026$ & $0.42(0.669)$ & 0.489 \\
\hline
\end{tabular}

HAM-D = the 17-item Hamilton Depression Rating Scale; CRP = C-reactive protein; IL6 = Inteleukin-6; GI = gastrointestinal; a - the listed figures represent mean scores and standard deviations; $b$ - Mann-Whitney U Test was used to compare the mean ranks of patients without significant inflammatory markers and the two subgroups of elevated inflammatory markers (only CRP and both CRP and IL-6, respectively); $*$ - The level of significance for all analyses was set at $\alpha=0.05$

The significantly higher scores at the insight item of the HAM-D scale in patients with MDD and elevated of both inflammatory markers, CRP and IL-6, compared to MDD patients group without elevated inflammatory markers $(0.71 \pm 0488$ vs. $0.29 \pm 0.588$; $\mathrm{p}=0.026$ ) can be interpreted by considering of two possible arguments. First, it may directly reflect a higher severity of depressive symptoms in comparison to the other two groups, with MDD but without elevated inflammatory markers and that of patients with MDD and only elevated CRP levels. Second, owing to the overexpression of somatic manifestations in the subgroup of MDD patients and both CRP and IL-6 elevated levels, the origin of the symptoms may be inappropriately assigned to other diseases, the most probable to a physical condition rather than to MDD. Further, extensive studies should be conducted to identify this hypothetical distinct phenotype of MDD with elevated underlying inflammatory markers.
The additional antidepressant effect of add-on treatment with celecoxib in patients with MDD

To estimate the efficacy of the add-on treatment with celecoxib on the severity of depressive symptoms in patients with MDD and peripheral inflammatory markers, we have further undertaken two distinct directions of data analyses.

The mean score differences on HAM-D scale within distinct subgroups, based on immune profile, at the endpoint comparing with baseline assessment of study Considering the three subgroups based on peripheral immune profiles determined at baseline, despite the initially higher mean score in the subgroup with both CRP and IL-6 elevated levels $(29.86 \pm 2.911)$, the mean change of scores during the study period has abruptly decreased in comparison with the group of non-elevated inflammatory MDD patients and the subgroup of MDD patients and only CRP elevated markers (22.143, 17.355 and 14.417 respectively, Table III). However, the mean change of scores was statistically significant for all three subgroups $(p<0.001)$ (Table III).

Table III

The efficacy of pharmacological treatment in all subjects grouped based on their immune profiles

\begin{tabular}{|l|c|c|c|c|}
\hline \multirow{2}{*}{ Subgroups based on immune profiles } & \multicolumn{4}{|c|}{ The 17-item HAMD-D total mean scores } \\
\cline { 2 - 5 } & HAM-D at baseline & HAM-D at 8 weeks & Mean change from baseline & $\mathrm{p}^{\text {value }}{ }^{\text {a }}$ \\
\hline Without inflammatory markers $(\mathrm{n}=31)$ & $24.19(5.759)$ & $6.84(2.782)$ & 17.355 & $*<0.001$ \\
\hline With elevated CRP \& IL-6 $(\mathrm{n}=7)$ & $29.86(2.911)$ & $7.71(3.039)$ & 22.143 & $*<0.001$ \\
\hline With only CRP elevated $(\mathrm{n}=12)$ & $25.92(4.852)$ & $11.50(2.646)$ & 14.417 & $*<0.001$ \\
\hline
\end{tabular}

HAM-D = the 17-item Hamilton Depression Rating Scale; CRP = C-reactive protein; IL6 = Inteleukin-6. The listed figures represent total mean scores and standard deviations; a - Paired-Samples t-Test was performed to compare the treatment efficacy within subgroups;

$*$ - The level of significance for all analyses was set at $\alpha=0.05$. 
This result could be influenced by the add-on treatment with celecoxib that was present in 6 of 7 patients in the subgroup with MDD and elevated levels of both CRP and IL-6, while the add-on celecoxib treatment was given in 6 of 12 patients in the subgroup with MDD and only CRP elevated levels.

The mean score differences on HAM-D scale between distinct subgroups, based on the presence of add-on treatment with celecoxib, at all the assessment moments in the study comparing with baseline assessment of study depending on the presence the add-on treatment with celecoxib

When the three arms of the study were taken into account (Figure 1) the differences of the mean HAM$\mathrm{D}$ total scores reached statistical significance at 6 weeks and at the endpoint of study $\left(\mathrm{F}_{2,47}=4.053, \mathrm{p}=0.024\right.$ and $F_{2,47}=12.585, p<0.001$ ) (Table IV). The effect size was stronger at the endpoint of study (partial $\left.\eta^{2}=0.349\right)$, more than two times stronger than that

at 6 weeks (partial $\eta^{2}=0.147$ ). So, it can be noticed that at endpoint the highest decrease in total mean scores of HAM-D was in the group of patients with MDD and non-elevated inflammatory markers closely followed by the subgroup of MDD patients with elevated inflammatory markers and add-on treatment with celecoxib $(6.84 \pm 2.782 v s .8 .67 \pm 2.774)$. In the subgroup of MDD patients with elevated inflammatory markers and without add-on treatment with celecoxib, the total mean score at 8 weeks was significantly higher compared to the other two groups $(12.57 \pm 2.699)$. Moreover, when the mean total scores at 8 weeks of MDD patients with elevated peripheral inflammatory markers were compared depending on add-on treatment with celecoxib, the difference was statistically significant in detriment of MDD patients with elevated inflammatory markers (CRP and/or IL-6) without add-on celecoxib treatment $(12.57 \pm 2.699$ vs. $8.67 \pm 2.774 ; \mathrm{p}=0.008)$ (Table IV).

Table IV

The dynamic of HAM-D scores in the three arms of study

\begin{tabular}{|c|c|c|c|c|c|}
\hline \multirow[b]{2}{*}{ HAM-D total scores } & \multirow{2}{*}{$\begin{array}{c}\text { Non-elevated } \\
\text { inflammatory markers } \\
(\mathrm{n}=31) \\
\text { arm A }\end{array}$} & \multicolumn{4}{|c|}{ Elevated inflammatory markers $(\mathrm{n}=19)$} \\
\hline & & $\begin{array}{l}\text { Without celecoxib add- } \\
\text { on treatment }(\mathrm{n}=7) \\
\text { arm B }\end{array}$ & $\begin{array}{c}\text { With celecoxib add-on } \\
\text { treatment }(\mathrm{n}=12) \\
\operatorname{arm~} \mathrm{C}\end{array}$ & $\mathrm{F} ; \mathrm{p}$ value $^{\mathrm{a}}$ & $\mathrm{p}$ value ${ }^{\mathrm{b}}$ \\
\hline HAM-D at baseline & $24.19(5.759)$ & $27.00(5.354)$ & $27.58(4.316)$ & $2.060 ; 0.139$ & 0.798 \\
\hline HAM-D at 2 weeks & $14.52(4.625)$ & $18.14(3.436)$ & $16.17(3.834)$ & $2.256 ; 0.116$ & 0.277 \\
\hline HAM-D at 4 weeks & $10.97(3.701)$ & $12.43(1.902)$ & $11.33(2.902)$ & $0.549 ; 0581$ & 0.387 \\
\hline HAM-D at 6 weeks & $8.74(3.076)$ & $12.29(2.289)$ & $9.50(3.030)$ & $4.053 ; * 0.024$ & 0.051 \\
\hline HAM-D at 8 weeks & $6.84(2.782)$ & $12.57(2.699)$ & $8.67(2.774)$ & $12.585 ; *<0.001$ & $* 0.008$ \\
\hline
\end{tabular}

HAM-D = the 17-item Hamilton Depression Rating Scale; CRP = C-reactive protein; IL6 = Inteleukin-6. The listed figures represent mean scores and standard deviations; a - One-way ANOVA Test was performed to compare mean total scores between all three subgroups; $\mathrm{b}$ - Independent - Samples t-Test was performed to compare mean total scores of the elevated inflammatory subgroups depending on the presence of add-on treatment with celecoxib; * The level of significance for all analyses was set at $\alpha=0.05$.

These results are in line with studies that have previously confirmed the antidepressant effectiveness of celecoxib in patients suffering from MDD and having elevated inflammatory markers [35-37].

The predictive value of peripheral inflammatory markers and add-on treatment with celecoxib on depressive symptoms severity at the endpoint ( 8 weeks) of the study

According to the linear model, the presence of inflammation (elevated CRP and/or IL-6 levels) was positive and significantly correlated with HAM-D mean scores at the endpoint of the study, predicting a higher severity of depression in MDD patients $(\beta=0.869, p<0.001)$. Separately, both peripheral inflammatory markers did not have predictive power on HAM-D score at the endpoint of the study $(p>0.05)$. Conversely, the presence of add-on treatment with celecoxib has predicted lower severity of depression at the endpoint of the study measured on HAM-D scale $(\beta=-0.507, p=0.008)$. It is noteworthy that the linear model has predicted $33 \%$ of the variance of the HAMD scores at the endpoint of the study (Table V). Again, our findings were fully consistent with data from other studies [8, 36-38].

Table V

The predictive value of peripheral inflammatory markers and add-on treatment with celecoxib on depressive symptoms severity at the endpoint ( 8 weeks) of the study

\begin{tabular}{|l|c|c|c|c|c|}
\hline & Unstandardized B & Standardized Beta & $\mathrm{p}^{2}$ value $^{\mathrm{c}}$ & \multicolumn{3}{|c|}{ 95\% Confidence Interval for B } \\
\cline { 5 - 6 } & Coefficients & Coefficients & & Lower Bound & Upper Bound \\
\hline IL-6 blood levels $^{\mathrm{a}}$ & -0.243 & -0.198 & 0.188 & -0.608 & 0.123 \\
\hline CRP blood levels $^{\mathrm{a}}$ & 0.175 & 0.185 & 0.189 & -0.089 & 0.438 \\
\hline Presence of inflammation $^{\mathrm{b}}$ & 5.959 & 0.869 & $*<0.001$ & 3.580 & 8.338 \\
\hline Add-on treatment with celecoxib $^{\mathrm{b}}$ & -3.951 & -0.507 & $* 0.008$ & -6.802 & -1.100 \\
\hline
\end{tabular}

Adjusted R Square of the model is 0.334; a - Quantitative variable; $b$ - Nominal dichotomic variable $(0$ - present, 1 - absent);

$\mathrm{c}$-Linear regression analysis was performed to estimate the association between inflammatory related parameters of patients with MDD and HAM-D scores at the endpoint of study; * The level of significance for all analyses was set at $\alpha=0.05$. 


\section{Conclusions}

Regardless of major advances concerning MDD treatment, there are still several unmet needs remaining. Finding innovative pathogenic mechanisms underlying MDD could open up new avenues for novel classes of psychotropic medication or the development of more clinical efficient therapeutic algorithms. Thus, the involvement of inflammatory markers in MDD is a clinical state of fact.

The presence of peripheral inflammatory markers could be considered as an impeding factor in the treatment of patients with MDD. In contrast, the addon treatment with celecoxib in MDD patients with elevated inflammatory markers could result in the better outcomes of the prescribed treatment.

In conclusion, we consider that the detection of inflammatory markers should become a routine and feasible clinical approach, and add-on celecoxib treatment would be warranted in MDD cases with coexisting chronic inflammatory processes.

\section{Acknowledgement}

This study was supported by a research grant (no. 8/07.03.2016) from Bioclinica Laboratories, Timișoara, Romania.

\section{Conflict of interest}

The authors declare no conflict of interest.

\section{References}

1. Rush AJ, Trivedi MH, Wisniewski SR, Nierenberg AA, Stewart JW, Warden D, Niederehe G, Thase ME, Lavori PW, Lebowitz BD, McGrath PJ, Rosenbaum JF, Sackeim HA, Kupfer DJ, Luther J, Fava M, Acute and longer-term outcomes in depressed outpatients requiring one or several treatment steps: a STAR*D report. Am J Psychiatry., 2006; 163(11): 1905-1917.

2. Massart R, Mongeau R, Lanfumey L, Beyond the monoaminergic hypothesis: neuroplasticity and epigenetic changes in a transgenic mouse model of depression. Philos Trans $R$ Soc Lond B Biol Sci., 2012; 367: 2485-2494.

3. Raison CL, Miller AH, Depression in cancer: new developments regarding diagnosis and treatment. Biol Psychiatry., 2003: 54(3): 283-294.

4. Song C, Wang H, Cytokines mediated inflammation and decreased neurogenesis in animal models of depression. Prog Neuropsychopharmacol Biol Psychiatry., 2011; 35: 760-768.

5. Khandaker GM, Pearson RM, Zammit S, Lewis G, Jones PB, Association of serum interleukin 6 and C-reactive protein in childhood with depression and psychosis in young adult life: a population-based longitudinal study. JAMA Psychiatry., 2014; 71(10): 1121-1128.

6. Khandaker GM, Zammit S, Burgess S, Lewis G, Jones PB, Association between a functional interleukin 6 receptor genetic variant and risk of depression and psychosis in a population-based birth cohort. Brain Behav Immun., 2018; 69: 264-272.

7. Howren MB, Lamkin DM, Suls J, Associations of depression with C-reactive protein, IL-1, and IL-6: a meta-analysis. Psychosom Med., 2009; 71: 171-186.

8. Köhler-Forsberg O, Buttenschøn HN, Tansey KE, Maier W, Hauser J, Dernovsek MZ, Henigsberg N, Souery D, Farmer A, Rietschel M, McGuffin P, Aitchison KJ, Uher R, Mors O, Association between C-reactive protein (CRP) with depression symptom severity and specific depressive symptoms in major depression. Brain Behav Immun., 2017; 62: 344-350.

9. Strawbridge R, Arnone D, Danese A, Papadopoulos A, Herane Vives A, Cleare AJ, Inflammation and clinical response to treatment in depression: A metaanalysis. Eur Neuropsychopharmacol., 2015; 25(10): 1532-1543.

10. Uher R, Tansey KE, Dew T, Maier W, Mors O, Hauser J, Dernovsek MZ, Henigsberg N, Souery D, Farmer A, McGuffin P, An inflammatory biomarker as a differential predictor of outcome of depression treatment with escitalopram and nortriptyline. Am J Psychiatry., 2014; 171(12): 1278-1286.

11. Köhler O, Benros ME, Nordentoft M, Farkouh ME, Iyengar RL, Mors O, Krogh J, Effect of antiinflammatory treatment on depression, depressive symptoms, and adverse effects: a systematic review and meta-analysis of randomized clinical trials. JAMA Psychiatry., 2014; 71(12): 1381-1391.

12. Nicolae AC, Mitrea N, Drăgoi CM, Constantinescu MZ, Ciofrângeanu C, Bărboi G, Arsene AL, Murine studies regarding the variation of oxidative status in serum, hepatic and brain samples, after administration of some cns active drugs. Farmacia, 2013; 61(4): 658-669.

13. Miller $\mathrm{AH}$, Maletic $\mathrm{V}$, Raison $\mathrm{CL}$, Inflammation and its discontents: the role of cytokines in the pathophysiology of major depression. Biol Psychiatry., 2009; 65: 732-741.

14. Kopschina Feltes P, Doorduin J, Klein HC, JuárezOrozco LE, Dierckx RA, Moriguchi-Jeckel CM, de Vries EF, Anti-inflammatory treatment for major depressive disorder: implications for patients with an elevated immune profile and non-responders to standard antidepressant therapy. J Psychopharmacol., 2017; 31(9): 1149-1165.

15. Stellwagen D, Beattie EC, Seo JY, Malenka RC, Differential regulation of AMPA receptor and GABA receptor trafficking by tumor necrosis factor-alpha. J Neurosci., 2005; 25: 3219-3228.

16. Anderson G, Kubera M, Duda W, Lasoń W, Berk M, Maes M, Increased IL-6 trans-signaling in depression: Focus on the tryptophan catabolite pathway, melatonin and neuroprogression. Pharmacol Rep., 2013; 65: 1647-1654.

17. Guillemin GJ, Quinolinic acid, the inescapable neurotoxin. FEBSJ 2012; 279: 1356-1365.

18. Savitz J, Drevets WC, Smith CM, Victor TA, Wurfel BE, Bellgowan PS, Bodurka J, Teague TK, Dantzer R, Putative neuroprotective and neurotoxic kynurenine pathway metabolites are associated with hippocampal and amygdalar volumes in subjects with major depressive disorder. Neuropsychopharmacology., 2015; 40(2): 463-471. 
19. Krishnadas R, McLean J, Batty DG, Burns H, Deans KA, Ford I, McConnachie A, McGinty A, McLean JS, Millar K, Sattar N, Shiels PG, Velupillai YN, Packard CJ, Cavanagh J, Cardio-metabolic risk factors and cortical thickness in a neurologically healthy male population: results from the psychological, social and biological determinants of ill health (pSoBid) study. Neuroimage Clin., 2013; 2: 646-657.

20. Swardfager W, Rosenblat JD, Benlamri M, McIntyre RS, Mapping inflammation onto mood: inflammatory mediators of anhedonia. Neurosci Biobehav Rev., 2016; 64: 148-166.

21. Maes M, Targeting cyclooxygenase-2 in depression is not a viable therapeutic approach and may even aggravate the pathophysiology underpinning depression. Metab Brain Dis., 2012; 27: 405-413.

22. Aïd S, Bosetti F, Targeting cyclooxygenases-1 and -2 in neuroinflammation: therapeutic implications. Biochimie, 2011; 93: 46-51.

23. Galecki P, Szemraj J, Bienkiewicz M, Zboralski K, Gałecka E, Oxidative stress parameters after combined fluoxetine and acetylsalicylic acid therapy in depressive patients. Hum Psychopharmacol., 2009; 24: 277-286.

24. Pasco JA, Nicholson GC, Williams LJ, Jacka FN, Henry MJ, Kotowicz MA, Schneider HG, Leonard $\mathrm{BE}$, Berk M: Association of high-sensitivity Creactive protein with de novo major depression. $\mathrm{Br}$ J Psychiatry, 2010; 197: 372-377.

25. Nery FG, Monkul ES, Hatch JP, Fonseca M, ZuntaSoares GB, Frey BN, Bowden CL, Soares JC, Celecoxib as an adjunct in the treatment of depressive or mixed episodes of bipolar disorder: a doubleblind, randomized, placebo-controlled study. Hum Psychopharmacol., 2008; 23: 87-94.

26. Adzic M, Brkic Z, Mitic M, Francija E, Jovicic MJ, Radulovic J, Maric NP, Therapeutic Strategies for Treatment of Inflammation-related Depression. Curr Neuropharmacol., 2018; 16(2): 176-209.

27. Warner-Schmidt JL, Vanover KE, Chen EY, Marshall JJ, Greengard P, Antidepressant effects of selective serotonin reuptake inhibitors (SSRIs) are attenuated by antiinflammatory drugs in mice and humans. Proc Natl Acad Sci USA., 2011; 108(22): 9262-9267.
28. First MB, Spitzer RL, Gibon M, Williams JBW. SCID-I RV (Research version). Romanian version: Coordinator Daniel David, Romanian Psychological Testing Services, 2007, "Babeș-Bolyai” University, Cluj-Napoca, Romania (ISBN: 978-973-1816-02-9).

29. Hamilton M, A rating scale for depression. J Neurol Neurosurg Psychiatry., 1960; 23: 56-62.

30. Pawelec G, Age and immunity: What is "immunosenescence"?. Exp Gerontol., 2018; 105: 4-9.

31. Rohleder N, Stress and inflammation - The need to address the gap in the transition between acute and chronic stress effects. Psychoneuroendocrinology., 2019;105:164-171.

32. Guffanti G, Gameroff MJ, Warner V, Talati A, Glatt CE, Wickramaratne P, Weissman MM, Heritability of major depressive and comorbid anxiety disorders in multi-generational families at high risk for depression. Am J Med Genet B Neuropsychiatr Genet., 2016; 171(8): 1072-1079.

33. Halaris A, Inflammation-associated co-morbidity between depression and cardiovascular disease. Curr Top Behav Neurosci., 2017; 31: 45-70.

34. Han KM, Kim MS, Kim A, Paik JW, Lee J, Ham BJ, Chronic medical conditions and metabolic syndrome as risk factors for incidence of major depressive disorder: A longitudinal study based on 4.7 million adults in South Korea. J Affect Disord., 2019; 257 : 486-494.

35. Abbasi SH, Hosseini F, Modabbernia A, Ashrafi M, Akhondzadeh S, Effect of celecoxib add-on treatment on symptoms and serum IL-6 concentrations in patients with major depressive disorder: randomized double-blind placebo-controlled study. J Affect Disord., 2012; 141(2-3): 308-314.

36. Na KS, Lee KJ, Lee JS, Cho YS, Jung HY, Efficacy of adjunctive celecoxib treatment for patients with major depressive disorder: a meta-analysis. Prog Neuropsychopharmacol Biol Psychiatry, 2014; 48: 79-85.

37. Baune BT, Are non-steroidal anti-inflammatory drugs clinically suitable for the treatment of symptoms in depression-associated inflammation?. Curr Top Behav Neurosci., 2017; 31: 303-319. 